\title{
Application of hypergravity in Eucalyptus and Corymbia seeds
}

\author{
Andrei Caíque Pires Nunes ${ }^{1 *}$ Glêison Augusto dos Santos ${ }^{1}$ Marlise Araújo dos Santos ${ }^{2}$ \\ Thais Russomano ${ }^{2}$ Osmarino Pires dos Santos $^{3}$ Brígida Maria dos Reis Teixeira Valente ${ }^{3}$ \\ Marcos Deon Vilela de Resende ${ }^{4}$
}

\begin{abstract}
${ }^{1}$ Departamento de Engenharia Florestal, Universidade Federal de Viçosa (UFV), Avenida Peter Henry Rolfs, s/n, Campus Universitário, Centro, 36570000, Viçosa, MG, Brasil. E-mail: andreicaiquep@gmail.com. *Corresponding author.

${ }^{2}$ Laboratório de Engenharia Aeroespacial Joan Vernikos, Centro de Microgravidade da Pontifícia, Universidade Católica do Rio Grande do Sul (PUCRS), Porto Alegre, RS, Brasil.

${ }^{3}$ CMPC Celulose Riograndense, Rua São Geraldo, Guaíba, RS, Brasil.

${ }^{4}$ Empresa Brasileira de Pesquisa Agropecuária, Centro Nacional de Pesquisa de Florestas, Estrada da Ribeira, Km 111, Bairro Guaraituba, Colombo, PR, Brasil.
\end{abstract}

ABSTRACT: The aim of this study was to evaluate the growth responses of various Eucalyptus and Corymbia species subjected to different intensities of simulated hypergravity relative to the control. A centrifuge was used to simulate hypergravity. It was developed and built at the Centro de Microgravidade of the Pontificia Universidade Católica do Rio Grande do Sul, Brazil. Seeds of five Eucalyptus and one Corymbia species (E. grandis, Eucalyptus globulus, Eucalyptus benthamii, Eucalyptus saligna, Eucalyptus dunnii, and C. maculata) were placed on moist germination paper in plastic containers and rotated at speeds simulating $5 \mathrm{Gz}$ and $7 \mathrm{Gz}$ for different lengths of time. Hypergravity technology significantly increased seedling production (diameter, height, and survival at 120 days) in nurseries. In E. globulus, the effects of hypergravity were significant at $7 \mathrm{Gz}$ at all lengths of time (from $1 \mathrm{~d}$ to 9 days). Effects of hypergravity were significant in both E. benthamii and E. grandis at $7 \mathrm{Gz}$ and 8 h exposure. Therefore, simulated hypergravity could be used in performance tests of Eucalyptus seedlings in early stages of development.

Key words: rowth increment; forest breeding; simulated-gravity.

\section{Aplicação da hipergravidade em sementes de Eucalyptus e Corymbia}

RESUMO: O presente trabalho objetivou avaliar o crescimento de espécies de Eucalyptus e Corymbia em diferentes intensidades de hipergravidade simulada em relação ao controle. Uma centrifuga foi usada para simular a hipergravidade. Este equipamento foi desenvolvido e construído no Centro de Microgravidade da Pontifícia Universidade Católica do Rio Grande do Sul, Brasil. Sementes de cinco espécies de Eucalyptus e uma de Corymbia (E. grandis, E. globulus, E. benthamii, E. saligna, E. dunnii, e C. maculata) foram colocadas em papeis de germinação e em recipientes plásticos, em que foram rotacionadas a velocidades simuladas de $5 \mathrm{Gz}$ e $7 \mathrm{Gz}$, por diferentes periodos de tempo. A tecnologia da hipergravidade proporcionou aumento significativo na taxa de crescimento das plântulas (diâmetro, altura e sobrevivência aos 120 dias) no viveiro. Para Eucalyptus globulus, os efeitos da hipergravidade foram significativos na intensidade de 7 Gz em qualquer periodo de tempo (do primeiro até o nono dia). Os efeitos da hipergravidade foram significativos para as espécies E. benthamii e E. grandis na intensidade 7 Gz e 8 horas de exposição. Dessa maneira, a hipergravidade simulada apresenta potencial de uso em testes com plântulas de eucaliptos em estágios iniciais de desenvolvimento.

Palavras-chave: incremento de crescimento; melhoramento do Eucalyptus e Corymbia; gravidade simulada.

\section{INTRODUCTION}

Eucalyptus improvement has placed the paper and cellulose divisions of the Brazilian forestry industry in a prominent position. Advances in productivity and wood quality are largely due to the development of interspecific Eucalyptus hybrids and the cloning of the best individuals from progeny (ASSIS \& MAFIA, 2007). Hybrids between Eucalyptus urophylla $\mathrm{x}$ E. grandis have been produced with favorable adaptation traits, rooting ability, resistance to Eucalyptus canker disease, and high yield (ASSIS et al., 1993; ASSIS \& MAFIA, 2007; BATISTA et al., 2014; CASTRO et al., 2016).

RESENDE \& ASSIS (2008) proposed reciprocal recurrent selection between synthetic multispecies populations (RRS-SMSP). In this method, genetically superior individuals are obtained with 
desirable traits present in several species. In the RRS-SMSP technique, two synthetic multi-species populations are obtained and recurrent selection is performed between them. In this way, it is possible to congregate desirable traits belonging to several species in an individual. Heterosis is exploited for growth by using several pairs of species whose combinations are known to be heterotic (RESENDE \& ASSIS, 2008).

RRS-SMSP is widely used in Eucalyptus improvement programs and this method has proven to be effective (ASSIS \& MAFIA, 2007; RESENDE \& ASSIS, 2008; CASTRO et al., 2016). Nevertheless, much time is required to conduct controlled breeding, obtain seeds, and assemble hybrid progeny tests. Therefore, methods are needed to obtain superior individuals in the shortest time possible and maximize genetic gains from the selection process. It has been reported that simulated hypergravity rapidly increases plant growth and the number of germinated seeds. It requires only that plant propagules be subjected to higher gravitational acceleration forces (G-force) than those on earth (RUSSOMANO et al., 2007; SANTOS et al., 2012).

Hypergravity can be simulated by using a centrifuge that combines several forces and produces a G-force that acts on the specimen. During centrifuge rotations, normal force balances the weight force while the centripetal force pulls the moving body towards the center of the circle. Inertia keeps it in the tangential direction. The resulting force is related to the $\mathrm{G}$ effect applied to the body (RUSSOMANO et al., 2007). It occurs in magnitudes higher than the Earth's gravitational force $(1 \mathrm{Gz})$ and may cause phenotypic changes in the plants subjected to it. It may also change seed germination patterns (HOSON et al., 1996; SOGA et al., 1999; NAKABAYASHI et al., 2006; RUSSOMANO et al., 2007; MATSUMOTO et al., 2010; MANZANO et al., 2012; SANTOS et al., 2012; HOSON, 2014).

Effects of simulated hypergravity on radish and cucumber (KASAHARA et al., 1995), watercress (HOSON et al., 1996), beans (SOGA et al., 1999), carrot (SANTOS et al., 2012), rocket (RUSSOMANO et al., 2007), Arabidopsis thaliana (NAKABAYASHI et al., 2006; MANZANO et al., 2012), and other Arabidopsis species (MATSUMOTO et al., 2010) have been studied. However, as yet, to our knowledge, no studies have reported the use of hypergravity to increase the growth and germination of Eucalyptus.

The aim of this study was to evaluate the growth responses of various Eucalyptus species subjected to different intensities of simulated hypergravity relative to the control $(1 \mathrm{Gz})$ in early stage of development (seedlings).

\section{MATERIALS AND METHODS}

The simulated hypergravity experiment was conducted at the Laboratório de Engenharia Aeroespacial Joan Vernikos and Centro de Microgravidade at the Pontifícia Universidade Católica do Rio Grande do Sul (FENG/PUCRS). Seed planting, management and assessment were carried out in 2015 at the nursery of the CMPC Celulose Riograndense Company, located in the municipality of Barra do Ribeiro, RS, in the Barba Negra Forestry Park (latitude $30^{\circ} 17^{\prime} \mathrm{S}$, longitude $51^{\circ} 18^{\prime} \mathrm{W}$ and altitude $12 \mathrm{~m}$ ). According to the Köppen classification, the prevailing climate in the region is of the Cfa type (humid subtropical) with an average annual rainfall of about $1400 \mathrm{~mm}$. The average temperature of the warmest month does not exceed $25^{\circ} \mathrm{C}$ and the coldest month $14^{\circ} \mathrm{C}$, with light frosts.

\section{Plant material}

A centrifuge designed and developed at the Centro de Microgravidade, PUCRS, was used to simulate hypergravity. Several Eucalyptus and one Corymbia species were used in this experiment. These included $E$. grandis (lot-00049 PSM. HF.Dura RS/ex.qld-Australia), E. globulus (lot 00012 - Otwai Range - Australia), E. benthamii (PSM - Ipiranga, RS), E. saligna (lot 00028 PSM - HF Jerônimo, RS/ex, QLD - NSW - Australia), C. maculata (lot 00002 - PSM - HF - Camélia, RS), and E. dunnii (lot 01 - PSM - CMPC). The CMPC Celulose Riograndense Company provided the plant materials and the experiments were conducted in 2015.

Exposure of seeds to intermittent simulated hypergravity - scenario 1

E. grandis and E. globulus seeds were placed on rectangular filter paper $(18 \mathrm{~cm}$ long by $7 \mathrm{~cm}$ wide) moistened with water. Fifteen seeds were placed $1 \mathrm{~cm}$ from the top edge of each filter paper. These were rolled and transferred into $300 \mathrm{~mL}$ containers. Three filter paper rolls were placed in each container ( 45 seeds per sample). To each container, $40 \mathrm{~mL}$ water was added. Each container was then covered with perforated plastic film to minimize evaporative water loss.

In this study, a simulated hypergravity of $7 \mathrm{Gz}$ was applied intermittently for 1, 2, 3, 4, 5, 6, 7 and $9 \mathrm{~d}$. The cycle was $8 \mathrm{~h}$ in simulated hypergravity and $16 \mathrm{~h}$ at rest $(1 \mathrm{Gz})$. Each protocol had a control group at rest $(1 \mathrm{Gz})$ under the same light and humidity conditions throughout the experiment. Protocols were carried out in triplicate.

After treatment with a simulated hypergravity of $7 \mathrm{Gz}$ at different exposure periods, the 
seeds of E. grandis and E. globulus were taken to a greenhouse to evaluate their survival rates (number of plants surviving out of 45 sown seeds), plant height $(\mathrm{cm})$, plant diameter $(\mathrm{cm})$, number of roots ( $\mathrm{n}^{\circ}$ roots), root wet weight $(\mathrm{WW}, \mathrm{g})$, and root dry weight (DW, g). Seeds were planted in a completely randomized block design. Seeds were planted in polypropylene tubes with a volume of $55 \mathrm{~cm}^{3}$ and the substrate was composed of $20 \%$ vermiculite and $80 \%$ Canadian peat. The base fertilizer of the substrate was a mixture containing PG mix $^{\mathrm{TM}}$, Super simple (phosphate) and Osmocote $^{\circledR} \quad$ (Scotts Miracle-GroCompany) (NPK $19: 06: 10)$, in a dosage concentration of $2.0 \mathrm{~kg}$, $2.0 \mathrm{~kg}$ and $1.5 \mathrm{~kg} \mathrm{~m}^{-3}$ of substrate, respectively. The greenhouse was equipped with a misting irrigation system using sprays nozzles with a flow rate of $7.5 \mathrm{~L}$ $\mathrm{h}^{-1}$, with automated control of moisture and water table irrigation. In all stages, the irrigation intensity varied according to weather conditions. For survival evaluation, 45 seeds were sown in triplicate in the greenhouse. Surviving plants were counted in the first- and second months after sowing. Four-monthold seedlings were sampled and evaluated in triplicate for growth traits, number of roots, WW, and DW. Four representative individuals were then selected from each replicate for evaluation.

Exposure of seeds to uninterrupted simulated hypergravity - scenario 2

E. grandis, E. globulus, E. benthamii, E. saligna, C. maculata, and E. dunnii seeds were placed on filter paper and into plastic containers as described previously. They were subjected to continuous $7 \mathrm{Gz}$ and $5 \mathrm{Gz}$ for $8 \mathrm{~h}$ and $24 \mathrm{~h}$. The control group consisted of seeds that did not receive hypergravity treatment. This procedure was repeated three times for each combination of $\mathrm{G}$ effect and exposure time. Sizes of the shoots and roots were recorded in the laboratory on day ten for all species.

After the $5 \mathrm{Gz}$ and $7 \mathrm{Gz}$ hypergravity treatments for $8 \mathrm{~h}$ and $24 \mathrm{~h}$, seeds were taken to the greenhouse to rate survival, plant height, plant diameter, number of roots, root wet weight, and root dry weight. Seeds were also planted in a completely randomized block design at the same nursery conditions described above. For the survival evaluation, 45 seeds were sown in triplicate in the greenhouse. Surviving plants were counted during the first- and second months after sowing. To evaluate the four-month-old plants, four representative individuals from each of the three replicates were chosen according to their growth traits, number of roots, WW, and DW.

\section{Statistical analysis}

The data were tested for normality using the Shapiro-Wilk test (1965), and each treatment was analyzed. The data were normally distributed at $5 \%$ probability level. To evaluate the laboratory and nursery data, a completely randomized block design in a factorial arrangement was used. The main factors were hypergravity intensity and exposure time. The interaction was hypergravity intensity $\mathrm{x}$ exposure time, and the treatments were the various combinations of hypergravity intensity and time. An analysis of variance (ANOVA) was performed on each variable. The significance of each factor was assessed separately using Duncan's test at a 5\% probability level. The significance of the interaction between gravity intensities and different timespans was also assessed. Scenarios 1 and 2 were considered separately in the statistical analysis. Statistical analyses were carried out with $\mathrm{R}$ Software (R Core Team, 2016).

\section{RESULTS AND DISCUSSION}

Exposure of seeds to intermittent simulated hypergravity - scenario 1

$7 \mathrm{Gz}$ hypergravity applied intermittently to E. globulus seeds increased nursery seedling survival, height, and diameter relative to the control (Table 1). In the $7 \mathrm{Gz}$ treatment of E. globulus seeds, seedlings survival, height, and diameter were about $55 \%, 12 \%$, and $14 \%$ greater than those of the untreated (control) seeds, respectively.

RUSSOMANO et al. (2007) tested the effect of intermittent exposure of Eruca sativa Mill (rocket) to $7 \mathrm{Gz}$. They reported that the hypergravitytreated seeds had higher germination potential than the untreated controls. Whereas untreated rocket seeds germinate within $4-7 \mathrm{~d}$, seeds treated with $7 \mathrm{Gz}$ germinated in only $3 \mathrm{~d}$. The authors also noted that seeds exposed to intermittent $7 \mathrm{Gz}$ produced seedlings that grew taller (average $3.2 \mathrm{~cm}$ ) than those derived from untreated control seeds (average $1.9 \mathrm{~cm})$. These data corroborated the results of this study (E. globulus seeds treated with $7 \mathrm{Gz}$ produced plants with greater diameters, heights and survival times than the controls, Table 1).

According to RUSSOMANO et al. (2007), hypergravity modifies auxin translocation in plants and increases their height relative to untreated controls. Auxin elongates subapical cells and affects phototropism, geotropism, and fruit development. Simulated hypergravity may have increased cell wall acidification, an important cell 
Table 1 - Means and statistical significance of intermittent E. grandis and E. globulus exposures to 7 G for 1, 2, 3, 4, 5, 6, 7, and 9 d (scenario 1) for survival (number of surviving plants derived from 45 seeds), plant height (cm), plant diameter (cm), number of roots ( $\mathrm{n}^{\mathrm{o}}$ roots), root wet weight $(\mathrm{WW}, \mathrm{g})$, and root dry weight $(\mathrm{DW}, \mathrm{g})$.

\begin{tabular}{|c|c|c|c|c|c|c|}
\hline \multirow{2}{*}{ Variable } & \multicolumn{3}{|c|}{ 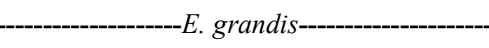 } & \multicolumn{3}{|c|}{ 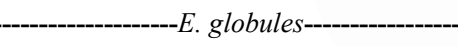 } \\
\hline & $1 \mathrm{Gz}^{*}$ & $7 \mathrm{Gz}$ & p-value & $1 \mathrm{Gz}^{*}$ & $7 \mathrm{Gz}$ & p-value \\
\hline Survival (number of plants) & 21.66 & 24.66 & $89 \%{ }^{\mathrm{NS}}$ & 6.58 & 10.21 & $0.0053 \% \mathrm{~S}$ \\
\hline Height $(\mathrm{cm})$ & 22.62 & 23.13 & $33 \%{ }^{\mathrm{NS}}$ & 12.53 & 14.07 & $0.18 \%^{\mathrm{s}}$ \\
\hline Diameter $(\mathrm{cm})$ & 2.55 & 2.82 & $24 \%{ }^{\mathrm{NS}}$ & 2.33 & 2.65 & $0.018 \%{ }^{\mathrm{S}}$ \\
\hline Roots (number) & 6.41 & 6.96 & $42 \%^{\mathrm{NS}}$ & 5.22 & 6.54 & $7 \%{ }^{\mathrm{NS}}$ \\
\hline WW (g) & 2.41 & 2.17 & $26 \%{ }^{\mathrm{NS}}$ & 3.32 & 3.33 & $98 \%{ }^{\mathrm{NS}}$ \\
\hline DW (g) & 0.43 & 0.42 & $96 \%{ }^{\mathrm{NS}}$ & 0.53 & 0.64 & $12 \%^{\mathrm{NS}}$ \\
\hline
\end{tabular}

*Control; S: effect of $7 \mathrm{G}$ significant at $5 \%$ probability level by the F-test; NS: effect of $7 \mathrm{G}$ not significant at $5 \%$ probability level by the Ftest; The time factor and the interaction between time and $\mathrm{G}$ intensity were not significant at the $5 \%$ probability level.

growth process that enhances the activity of the enzyme associated with cell wall malleability and elongation. Osmotic pressure forces water into the cell and makes it expand (RUSSOMANO et al., 2007).

There were no significant differences among the various hypergravity exposure time. This result demonstrated that for E. globulus species, the application of $7 \mathrm{Gz}$ force worked from $24 \mathrm{~h}$ intermittent exposure ( $8 \mathrm{~h}$ exposure to $7 \mathrm{Gz}$ and $16 \mathrm{~h}$ at rest) for the variables of survival, height and seedling diameter. Interaction between exposure time and hypergravity intensity was not significant. Therefore, exposure time and hypergravity intensity act independently in Eucalyptus.
Exposure of seeds to uninterrupted simulated hypergravity - scenario 2

There was no statistical significance in relation to the increase of plant growth due to hypergravity for any of the Eucalyptus species or variables evaluated in the laboratory (Table 2). Duncan's test was carried out to compare the means of the centrifugal groups (seeds that received $7 \mathrm{Gz}$ treatment) and control groups $(1 \mathrm{Gz})$. There were no increases in aerial shoot height (AP, $\mathrm{cm}$ ) or root length (root $\mathrm{S}, \mathrm{cm}$ ) due to the application of $7 \mathrm{Gz}$. Nevertheless, both shoot- and root growth were relatively higher in the untreated control (Table 2). E. saligna roots were $43 \%$ higher in the control than the centrifugal group. For C. maculata, $43 \%$

Table 2 - Means of the main factors studied for $8 \mathrm{~h}$ and $24 \mathrm{~h}$ continuous $7 \mathrm{Gz}$ and $5 \mathrm{Gz}$ treatments (scenario 2) and the respective control groups for E. grandis, E. globulus, E. benthamii, E. saligna, C. maculata, and E. dunnii. The variables evaluated in laboratory were aerial shoot height $(\mathrm{AP}, \mathrm{cm})$ and root length (root $\mathrm{S}, \mathrm{cm})$.

\begin{tabular}{|c|c|c|c|c|c|c|}
\hline \multirow{2}{*}{ Hypergravity intensities and controls } & \multicolumn{2}{|c|}{ 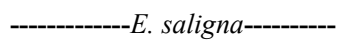 } & \multicolumn{2}{|c|}{-C. maculata---_-- } & \multicolumn{2}{|c|}{-------E. benthamii------- } \\
\hline & $\mathrm{AP}(\mathrm{cm})$ & Root S (cm) & $\mathrm{AP}(\mathrm{cm})$ & Root S (cm) & $\mathrm{AP}(\mathrm{cm})$ & Root S (cm) \\
\hline $7 \mathrm{Gz}$ & $0.44^{\mathrm{a}}$ & $0.46^{\mathrm{b}}$ & $0.93^{\mathrm{b}}$ & $1.15^{\mathrm{c}}$ & $1.01^{\mathrm{a}}$ & $1.17^{\mathrm{a}}$ \\
\hline Control & $0.56^{\mathrm{a}}$ & $0.66^{\mathrm{a}}$ & $1.15^{\mathrm{b}}$ & $1.65^{\mathrm{b}}$ & $1.04^{\mathrm{a}}$ & $1.22^{\mathrm{a}}$ \\
\hline $5 \mathrm{Gz}$ & $0.48^{\mathrm{a}}$ & $0.39^{\mathrm{b}}$ & $1.64^{\mathrm{a}}$ & $1.92^{\mathrm{b}}$ & $0.91^{\mathrm{b}}$ & $1.21^{\mathrm{a}}$ \\
\hline Control & $0.47^{\mathrm{a}}$ & $0.45^{\mathrm{b}}$ & $1.82^{\mathrm{a}}$ & $2.35^{\mathrm{a}}$ & $0.88^{\mathrm{b}}$ & $1.26^{\mathrm{a}}$ \\
\hline \multirow{2}{*}{ Hypergravity intensities and controls } & \multicolumn{2}{|c|}{-------------E. dunnii---------- } & \multicolumn{2}{|c|}{------E. globulus------ } & \multicolumn{2}{|c|}{-----------E. grandis---------- } \\
\hline & $\mathrm{AP}(\mathrm{cm})$ & Root S (cm) & $\mathrm{AP}(\mathrm{cm})$ & Root S (cm) & $\mathrm{AP}(\mathrm{cm})$ & Root S (cm) \\
\hline $7 \mathrm{G}$ & $1.34^{\mathrm{a}}$ & $1.28^{\mathrm{a}}$ & $0.81^{\mathrm{ab}}$ & $1.02^{\mathrm{ab}}$ & $0.74^{\mathrm{a}}$ & $0.78^{\mathrm{a}}$ \\
\hline Control & $1.25^{\mathrm{a}}$ & $1.40^{\mathrm{a}}$ & $0.94^{\mathrm{a}}$ & $1.37^{\mathrm{a}}$ & $0.84^{\mathrm{a}}$ & $0.85^{\mathrm{a}}$ \\
\hline $5 \mathrm{G}$ & $1.31^{\mathrm{a}}$ & $1.19^{\mathrm{a}}$ & $0.80^{\mathrm{ab}}$ & $1.10^{\mathrm{ab}}$ & $0.77^{\mathrm{a}}$ & $0.64^{\mathrm{b}}$ \\
\hline Control & $1.20^{\mathrm{a}}$ & $1.33^{\mathrm{a}}$ & $0.58^{\mathrm{b}}$ & $0.76^{\mathrm{b}}$ & $0.79^{a}$ & $0.77^{\mathrm{ab}}$ \\
\hline
\end{tabular}

Means for each species and variable followed by the same vertical letters do not significantly differ according to Duncan's test at a 5\% probability level. The main effect of time and the interaction between time and Gz intensity were not significant according to the ANOVA F-test. 
and $22 \%$ increases were measured for Root $\mathrm{S}$ in both control groups, respectively. These results showed that we can predict neither the direction nor the magnitude of the seedling responses to simulated hypergravity.
Application of $7 \mathrm{Gz}$ to $E$. benthamii and $E$. grandis seeds had a statistically significant effect on the seedlings derived from them in the nursery (Table 3). E. benthamii seeds exposed to $7 \mathrm{Gz}$ produced seedlings with significantly greater

Table 3 - Means of the main factors studied for $8 \mathrm{~h}$ and $24 \mathrm{~h}$ continuous $7 \mathrm{Gz}$ and $5 \mathrm{Gz}$ treatments (scenario 2) and the respective control groups for E. grandis, E. globulus, E. benthamii, E. saligna, C. maculata and E. dunnii. Variables evaluated in the nursery were: survival (number of surviving plants derived from 45 seeds), plant height $(\mathrm{cm})$, plant diameter $(\mathrm{cm})$, number of roots $\left(\mathrm{n}^{\circ}\right.$ roots), root wet weight $(\mathrm{WW}, \mathrm{g})$, and root dry weight $(\mathrm{DW}, \mathrm{g})$.

\begin{tabular}{|c|c|c|c|c|c|c|}
\hline \multirow{2}{*}{ Hypergravity intensities and controls } & \multicolumn{6}{|c|}{$\begin{array}{l}- \\
-\end{array}$} \\
\hline & $\begin{array}{l}\text { Survival } \\
\text { (number) }\end{array}$ & $\begin{array}{l}\text { Height } \\
\text { (cm) }\end{array}$ & $\begin{array}{l}\text { Diameter } \\
\quad(\mathrm{cm})\end{array}$ & $\begin{array}{c}\text { Roots } \\
\text { (number) }\end{array}$ & $\begin{array}{l}\text { WW } \\
(\mathrm{cm})\end{array}$ & $\begin{array}{l}\text { DW } \\
(\mathrm{cm})\end{array}$ \\
\hline $7 \mathrm{G}$ & $0.83^{\mathrm{b}}$ & $18.05^{\mathrm{b}}$ & $2.52^{\mathrm{a}}$ & $6.66^{\mathrm{b}}$ & $2.08^{\mathrm{b}}$ & $0.36^{\mathrm{a}}$ \\
\hline Control & $0.66^{\mathrm{b}}$ & $16.95^{\mathrm{b}}$ & $2.33^{\mathrm{a}}$ & $6.33^{b}$ & $1.64^{\mathrm{b}}$ & $0.40^{\mathrm{a}}$ \\
\hline $5 \mathrm{G}$ & $3.16^{\mathrm{b}}$ & $20.5^{\mathrm{a}}$ & $2.56^{\mathrm{b}}$ & $8.66^{\mathrm{a}}$ & $2.80^{\mathrm{a}}$ & $0.37^{\mathrm{a}}$ \\
\hline \multirow[t]{3}{*}{ Control } & $6.5^{\mathrm{a}}$ & $21.5^{\mathrm{a}}$ & $2.38^{\mathrm{b}}$ & $10.08^{\mathrm{a}}$ & $2.81^{\mathrm{a}}$ & $0.34^{\mathrm{a}}$ \\
\hline & \multicolumn{6}{|c|}{ 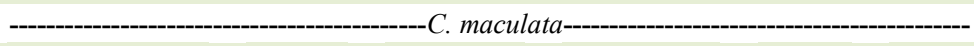 } \\
\hline & $\begin{array}{l}\text { Survival } \\
\text { (number) }\end{array}$ & $\begin{array}{l}\text { Height } \\
(\mathrm{cm})\end{array}$ & $\begin{array}{l}\text { Diameter } \\
\quad(\mathrm{cm})\end{array}$ & $\begin{array}{c}\text { Roots } \\
\text { (number) }\end{array}$ & $\begin{array}{l}\text { WW } \\
(\mathrm{cm})\end{array}$ & $\begin{array}{l}\text { DW } \\
(\mathrm{cm})\end{array}$ \\
\hline $7 \mathrm{G}$ & $10.83^{\mathrm{b}}$ & $20.37^{\mathrm{a}}$ & $2.77^{\mathrm{a}}$ & $5.0^{\mathrm{a}}$ & $3.34^{\mathrm{a}}$ & $0.64^{\mathrm{a}}$ \\
\hline Control & $10.83^{\mathrm{b}}$ & $21.04^{\mathrm{a}}$ & $2.69^{\mathrm{a}}$ & $3.0^{\mathrm{ab}}$ & $1.71^{\mathrm{a}}$ & $0.35^{\mathrm{a}}$ \\
\hline $5 \mathrm{G}$ & $17.16^{\mathrm{a}}$ & $18^{\mathrm{b}}$ & $2.70^{\mathrm{a}}$ & $2.0^{\mathrm{ab}}$ & $2.00^{\mathrm{a}}$ & $0.42^{\mathrm{a}}$ \\
\hline \multirow[t]{3}{*}{ Control } & $16.33^{\mathrm{a}}$ & $17^{\mathrm{b}}$ & $2.60^{\mathrm{a}}$ & $2.67^{b}$ & $2.27^{\mathrm{a}}$ & $0.53^{\mathrm{a}}$ \\
\hline & \multicolumn{6}{|c|}{ 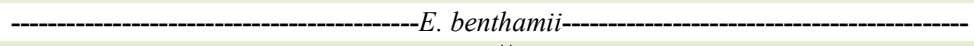 } \\
\hline & $\begin{array}{l}\text { Survival } \\
\text { (number) }\end{array}$ & $\begin{array}{l}\text { Height } \\
\text { (cm) }\end{array}$ & $\begin{array}{l}\text { Diameter } \\
(\mathrm{cm})\end{array}$ & $\begin{array}{c}\text { Roots } \\
\text { (number) }\end{array}$ & $\begin{array}{l}\text { WW } \\
(\mathrm{cm})\end{array}$ & $\begin{array}{l}\text { DW } \\
(\mathrm{cm})\end{array}$ \\
\hline $7 \mathrm{G}$ & $13.83^{\mathrm{a}}$ & $20.91^{\mathrm{a}}$ & $2.63^{\mathrm{a}}$ & $5.16^{\mathrm{b}}$ & $2.43^{\mathrm{a}}$ & $0.41^{\mathrm{a}}$ \\
\hline Control & $11.66^{\mathrm{a}}$ & $19.29^{\mathrm{a}}$ & $2.28^{\mathrm{b}}$ & $4.33^{\mathrm{b}}$ & $1.92^{\mathrm{b}}$ & $0.33^{\mathrm{a}}$ \\
\hline $5 \mathrm{G}$ & $8.33^{\mathrm{b}}$ & $20.91^{\mathrm{a}}$ & $2.36^{\mathrm{b}}$ & $6.5^{\mathrm{a}}$ & $2.38^{\mathrm{a}}$ & $0.37^{\mathrm{a}}$ \\
\hline \multirow[t]{3}{*}{ Control } & $2.33^{\mathrm{b}}$ & $19.29^{\mathrm{a}}$ & $2.42^{\mathrm{b}}$ & $7.5^{\mathrm{a}}$ & $2.57^{\mathrm{a}}$ & $0.28^{\mathrm{a}}$ \\
\hline & \multicolumn{6}{|c|}{ 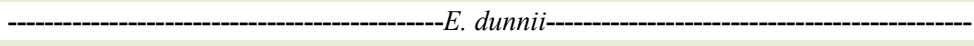 } \\
\hline & $\begin{array}{l}\text { Survival } \\
\text { (number) }\end{array}$ & $\begin{array}{l}\text { Height } \\
(\mathrm{cm})\end{array}$ & $\begin{array}{l}\text { Diameter } \\
\quad(\mathrm{cm})\end{array}$ & $\begin{array}{c}\text { Roots } \\
\text { (number) }\end{array}$ & $\begin{array}{l}\text { WW } \\
(\mathrm{cm})\end{array}$ & $\begin{array}{l}\text { DW } \\
(\mathrm{cm})\end{array}$ \\
\hline $7 \mathrm{G}$ & $7^{\mathrm{b}}$ & $17.25^{\mathrm{a}}$ & $2.46^{\mathrm{a}}$ & $9.83^{\mathrm{a}}$ & $2.77^{\mathrm{a}}$ & $0.37^{\mathrm{a}}$ \\
\hline Control & $5^{\mathrm{b}}$ & $15.62^{\mathrm{a}}$ & $2.38^{\mathrm{a}}$ & $9.00^{\mathrm{a}}$ & $2.90^{\mathrm{a}}$ & $0.43^{\mathrm{a}}$ \\
\hline $5 \mathrm{G}$ & $22.33^{\mathrm{a}}$ & $17.87^{\mathrm{a}}$ & $2.45^{\mathrm{a}}$ & $6.66^{\mathrm{a}}$ & $2.17^{\mathrm{a}}$ & $0.29^{\mathrm{a}}$ \\
\hline \multirow[t]{3}{*}{ Control } & $19.33^{\mathrm{a}}$ & $18.91^{\mathrm{a}}$ & $2.43^{\mathrm{a}}$ & $7.58^{\mathrm{a}}$ & $3.00^{\mathrm{a}}$ & $0.35^{\mathrm{a}}$ \\
\hline & \multicolumn{6}{|c|}{ 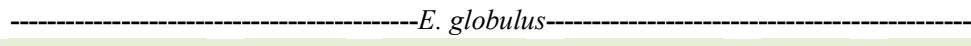 } \\
\hline & $\begin{array}{l}\text { Survival } \\
\text { (number) }\end{array}$ & $\begin{array}{l}\text { Height } \\
(\mathrm{cm})\end{array}$ & $\begin{array}{l}\text { Diameter } \\
\quad(\mathrm{cm})\end{array}$ & $\begin{array}{c}\text { Roots } \\
\text { (number) }\end{array}$ & $\begin{array}{l}\text { WW } \\
(\mathrm{cm})\end{array}$ & $\begin{array}{l}\text { DW } \\
(\mathrm{cm})\end{array}$ \\
\hline $7 \mathrm{G}$ & $1.16^{\mathrm{b}}$ & - & - & - & - & - \\
\hline Control & $0.16^{\mathrm{b}}$ & - & - & - & - & - \\
\hline $5 \mathrm{G}$ & $9.5^{\mathrm{a}}$ & - & - & - & - & - \\
\hline \multirow[t]{3}{*}{ Control } & $6.66^{\mathrm{a}}$ & - & - & - & - & - \\
\hline & \multicolumn{6}{|c|}{ - } \\
\hline & $\begin{array}{l}\text { Survival" } \\
\text { (number) }\end{array}$ & $\begin{array}{l}\text { Height } \\
(\mathrm{cm})\end{array}$ & $\begin{array}{l}\text { Diameter } \\
\quad(\mathrm{cm})\end{array}$ & $\begin{array}{c}\text { Roots } \\
\text { (number) }\end{array}$ & $\begin{array}{l}\text { WW } \\
(\mathrm{cm})\end{array}$ & $\begin{array}{l}\text { DW } \\
(\mathrm{cm})\end{array}$ \\
\hline $7 \mathrm{G}$ & $16.66^{\mathrm{a}}$ & $24.20^{\mathrm{a}}$ & $2.64^{\mathrm{a}}$ & $3.16^{\mathrm{b}}$ & $3.46^{\mathrm{a}}$ & $0.53^{\mathrm{a}}$ \\
\hline $5 \mathrm{G}$ & $10.16^{\mathrm{c}}$ & $19.33^{\mathrm{b}}$ & $2.42^{\mathrm{b}}$ & $8.16^{\mathrm{a}}$ & $2.09^{\mathrm{a}}$ & $0.31^{\mathrm{a}}$ \\
\hline Control & $11.83^{\mathrm{c}}$ & $24.33^{\mathrm{a}}$ & $2.38^{\mathrm{b}}$ & $8.33^{\mathrm{a}}$ & $2.28^{\mathrm{a}}$ & $0.35^{\mathrm{a}}$ \\
\hline
\end{tabular}

Means followed by the same vertical letters do not significantly differ by Duncan's test at a 5\% probability level. - death of the plant; ${ }^{*}$ Significant effects of $7 \mathrm{G}$ (individual) and time (individual) $(\mathrm{P}=0.001 \%)$. Plant survival rates were highest when seeds exposed to hypergravity for $24 \mathrm{~h}$. No interaction was reported between gravity intensity and exposure time; ${ }^{* *}$ Significant effect of $7 \mathrm{G}$ (individual). Effect of time (individual) not significant $(p=70 \%)$. No interaction wasreported between gravity intensity and exposure time. 
seedling diameters than those of the controls according to Duncan's test at the $5 \%$ probability level (Table 3). Seedlings treated with $7 \mathrm{Gz}$ were $15 \%$ larger in diameter than the untreated controls.

Seed treatment with $7 \mathrm{Gz}$ uninterrupted for $8 \mathrm{~h}$ and $24 \mathrm{~h}$ increased $E$. grandis seedling survival relative to controls according to Duncan's test at a $5 \%$ probability level (Table 3 ). For E. grandis, the $7 \mathrm{Gz}$ treatment increased seedling survival by $28 \%$ more than the control (Table 3 ). In addition, the time effect was significant by the ANOVA F-test at a $5 \%$ probability level: the survival rate was highest with the $8 \mathrm{~h}$ exposure time (Table 3 ).

SANTOS et al. (2012) evaluated the germination potential of Daucus carota L. exposed to $7 \mathrm{Gz}$ for $8 \mathrm{~h}$ followed by $16 \mathrm{~h}$ rest. This procedure was repeated for four consecutive days. The authors reported that a higher percentage of carrot seeds treated with $7 \mathrm{Gz}$ germinated than the untreated controls. The $8.89 \%, 12.35 \%$, and $15.06 \%$ increases in germination rate relative to the controls were obtained for hypergravity-treated carrot seeds on the fourth, eleventh, and eighteenth days of evaluation, respectively. These results corroborated the findings of this present study.

Very high magnitudes of hypergravity affected plant propagule growth. HOSON et al. (1996) reported that growth suppression occurred in watercress (Lepidium sativum L.) seedlings derived from seeds exposed to gravity exceeding $35 \mathrm{Gz}$. According to these authors, hypergravity at high levels causes cell walls to thicken and stiffen, and increase the lignin content. These alterations in cell wall metabolism inhibit cell growth and elongation.

KASAHARA et al. (1995) studied the effects of hypergravity on radish and cucumber and concluded that plant growth was reduced at $20 \mathrm{Gz}$. Nevertheless, the growth of seedlings subjected to $13 \mathrm{Gz}$ was not affected, and did not significantly differ from that of the control. MATSUMOTO et al. (2010) studied the effect of hypergravity on Arabidopsis thaliana and concluded that $300 \mathrm{Gz}$ suppressed growth. Gravitational conditions affect the morphology and mechanical properties of xylem vessels (NAKABAYASHI et al., 2006). As hypergravity intensifies, polysaccharides deposition increases, cells become more rigid and their growth is inhibited (SOGA et al., 1999). Therefore, the hypergravity intensities applied in the present study suffice to increase Eucalyptus growth and yield.

Statistically significant increases in $E$. benthamii diameter in response to $7 \mathrm{Gz}$ exposures may mean enhanced short-term growth and a breakthrough in Eucalyptus improvement. MANZANO et al. (2012) obtained higher Arabidopsis thaliana seedling lengths after subjecting seeds to $2 \mathrm{Gz}$ and $6 \mathrm{Gz}$ for $4 \mathrm{~d}$. They attributed the increase in length to changes in cell wall components. High levels of gravity may modify physiological processes by inducing mutations and/ or epigenetic changes (i.e., phenotypic alteration that does not result from changes in the DNA nucleotide sequence; ALBERTS et al., 2015).

Modifications caused by genetic and/ or epigenetic factors may benefit, injure or kill plants derived from seeds exposed to hypergravity. According to the present study, the mechanism by which these changes occur varies with plant species. Unlike the other Eucalyptus species, $7 \mathrm{Gz}$ hypergravity increased E. grandis survival rates relative to untreated controls. As discussed in scenario 1 , then, it is not yet possible to predict the direction or the magnitude of the effect caused by the application of hypergravity in Eucalyptus.

Unlike the laboratory data, those obtained from the nursery experiments were statistically significant. Therefore, it is assumed that the effect of simulated hypergravity is expressed throughout the Eucalyptus growth cycle. It is expected that even stronger effects of hypergravity would be observed in field trials using trees old enough to be harvested.

\section{CONCLUSION}

Simulated hypergravity technology enabled significant increases in nursery Eucalyptus seedling production (in terms of diameter, height, and survival at $120 \mathrm{~d}$ ) for different species and at various hypergravity intensities and durations. Based on the results obtained in the present study, it is feasible that simulated hypergravity could be used to improve Eucalyptus growth and merits further investigation.

\section{ACKNOWLEDGMENTS}

We thank the CMPC Celulose Riograndense Company, the Laboratório de Engenharia Aeroespacial Joan Vernikos and Centro de Microgravidade at the Pontifícia Universidade Católica do Rio Grande do Sul (FENG/PUCRS), the Universidade Federal de Viçosa (UFV), the Conselho Nacional de Desenvolvimento Científico e Tecnológico (CNPq, Brasília - DF, Brazil), and the Coordenação de Aperfeiçoamento de Pessoal de Nível Superior (CAPES, Brasília - DF, Brazil).

\section{REFERENCES}

ASSIS, T. F. et al. Sintetização de híbridos de Eucalyptus por cruzamentos controlados. Ciência Florestal, v. 3, p. 161-170. 1993. Available from: <http://coral.ufsm.br/cienciaflorestal/artigos/v3n1/ art10v3n1.pdf>. Acessed: sept. 09, 2016. doi: 10.5902/19805098. 
ASSIS, T. F.; MAFIA, R. G. Hibridação e clonagem. In: Borém, A. (ed.) Biotecnologia Florestal. Viçosa [s.n.], p. 93-121, 2007.

ALBERTS, B. et al. Molecular Biology of the Cell. 6 th ed. NewYork: Garland Science, 2015.

BATISTA, A. et al. Influence of basal cutting system of minicutings in clonal propagation of Eucalyptus urophylla x Eucalyptus globulus subsp. maidenii hybrid. Revista Árvore, v. 38, p. 1115-1122, 2014. Available from: <http://www.scielo.br/pdf/rarv/v38n6/a16v38n6.pdf $>$. Acessed: 01, dec. 2016. doi: 10.1590/S0100-67622014000600016.

CASTRO, C. A. O. et al. Brief history of Eucalyptus breeding in Brazil under perspective of biometric advances. Ciência Rural, v. 46, n. 9, p.1585-1593, 2016. Available from: <http://www.scielo.br/ pdf/cr/v46n9/1678-4596-cr-0103_8478cr20150645.pdf >. Acessed: 05, dec. 2016. doi: 10.1590/0103-8478cr20150645.

HOSON, T. et al. Effects of hypergravity on growth and cell wall properties of cress hypocotyls. Journal of Experimental Botany, v. 47, n. 297 , p. $513-517,1996$.

HOSON, T. Plant growth and morphogenesis under Different Gravity Conditions: Relevance to Plant Life in Space. Life. v 4, p. 205-216, 2014. doi:10.3390/life4020205.

KASAHARA, H. et al. Effects of Hypergravity on the Elongation Growth in Radish and Cucumber Hypocotyls. J. Plant Res. v. 108 p. 59-64, 1995

MANZANO, A. I. et al. Hypergravity environment induced by Centrifugation Alters Plant Cell Proliferation and Growth in an Opposite Way to Microgravity. Microgravity Sci. Technol. v. 24, v. 373-381, 2012. Available from: <https://link.springer.com/ article/10.1007/s12217-012-9301-1>. Acessed: 16, nov. 2016. doi: 10.1007/s12217-012-9301-1.

MATSUMOTO, S. et al. Gravity-induced modifications to Development in Hypocotyls of Arabidopsis Tubulin Mutants. Plant Physiology. v 152, p. 918-926, 2010.

NAKABAYASHI, I. et al. Hypergravity Stimulus Enhances Primary Xylem Development and Decreases Mechanical Properties of Secondary Cell Walls in Inflorescence Stems of Arabidopsis thaliana. Annals of Botany. v. 97, p. 1083-1090, 2006.

RESENDE, M.D.V.; ASSIS, T.F. Seleção Recorrente Recíproca entre Populações Sintéticas Multi- Espécies (SRR-PSME) de Eucalipto. Pesquisa Florestal Brasileira, p. 57-60, 2008 Available from: <http://pfb.cnpf.embrapa.br/pfb/index.php/pfb/ article/view/57/56> Acessed: 10, nov. 2016.

RUSSOMANO, T. et al. Effects of simulated hypergravityon BiomedicalExperiments. Ieee Engineering in Medicine And Biology Magazine. p. 1 - 6, 2007.

SANTOS, M. A. et al. Effect of hypergravity Simulation on Carrot Germination and Growth. Aviation, Space, and Environmental Medicine. v. 83, n. 10, 2012.

SHAPIRO, S. S. E M. B. WILK (1965) An Analysis of variance test for Normality (Complete Samples). Biometrika Trust, v. 52, p. 591-609. 3/4 (Dec., 1965). Available from: <http://www. jstor.org/ stable/2333700>.

SOGA, K. et al. Hypergravity increases the molecular Mass of Xyloglucans by Decreasing Xyloglucan-Degrading Activity in Azuki Bean Epicotyls. Plant Cell Physiol. v. 40, n. 6, p. 581-585, 1999. 